To cite: $\mathrm{R}$ Adeola 'The responsibility of businesses to prevent development-induced displacement in Africa' (2017) 17 African Human Rights Law Journal 244-264

http://dx.doi.org/10.17159/1996-2096/2017/v17n1a11

\title{
The responsibility of businesses to prevent development-induced displacement in Africa
}

\author{
Romola Adeola* \\ Steinberg Postdoctoral Fellow in International Migration Law and Policy, \\ Centre for Human Rights and Legal Pluralism, Faculty of Law, McGill \\ University, Montreal, Quebec, Canada
}

\begin{abstract}
Summary
Business-related development-induced displacement is a growing challenge in Africa. Thousands of individuals have been displaced due to private investment projects in various sectors, including the extractive industries, agriculture and infrastructural development. While much attention has been given to the responsibility of states as primary duty bearers in international law, the matter of the responsibility of businesses within the context of development-induced displacement has not been discussed. Utilising the United Nations Guiding Principles on Business and Human Rights, this article discusses the responsibility of businesses in preventing arbitrary development-induced displacement in Africa.
\end{abstract}

Key words: business and human rights; internal displacement; development projects; Africa; corporate responsibility

\section{Introduction}

Arising from the narrative of development-induced displacement is the tension between the development imperative of projects and the rights of persons likely to be displaced. ${ }^{1}$ When African countries started gaining independence in the twentieth century, the implementation of development projects was considered a significant

(LLD) (Pretoria); aderomola.ade@gmail.com

I R Adeola 'The legal protection of development-induced displaced persons under the African Union IDP Convention' (2017) 10 African Journal of Legal Studies 1. 
step in economically positioning Africa with the rest of the world. ${ }^{2}$ Projects such as dams, urban highways, the extraction of natural resources and infrastructural development were central to national economic policies. While their potential for stimulating growth is often lauded, they also create socio-economic impoverishment for local communities. For decades, issues of inadequate consultation, insufficient compensation, coercion, unsuitable resettlement and violent displacement have characterised this form of displacement in Africa. Recognising the need to address the various root causes of internal displacement, including development-induced displacement, the African Union (AU) in 2009 adopted a regional framework on internal displacement. ${ }^{3}$ In article 10 of the African Union Convention for the Protection and Assistance of Internally-Displaced Persons in Africa (Kampala Convention), states are mandated to prevent displacement caused by projects carried out by public and private actors. Private actors in this provision refer to businesses. However, the Kampala Convention does not discuss what the responsibility of businesses entails within the context of development-induced displacement. With reference to the existing international framework on business and human rights, the article analyses the responsibility of businesses to prevent arbitrary development-induced displacement in Africa.

\section{Business and development-induced displacement in Africa}

One of the ways in which the adverse human rights impact of business activities has featured in Africa is in relation to developmentinduced displacement. In Africa, this impact has reverberated in the context of natural resource extraction. The coal-mining-induced displacement in Mozambique is instructive. ${ }^{4}$ Between 2009 and 2014, more than 2000 families were displaced from their place of residence in communities in the Tete province to make way for mining activities by corporate giants - Vale and Rio Tinto. ${ }^{5}$ Although resettlement was initiated by the corporations and displaced persons were moved to Cateme village, Mwaladzi and a place called 25 de Setembro which is

2 SF Miescher \& D Tsikata 'Hydro-power and the promise of modernity and development in Ghana: Comparing the Akosombo and Bui dam projects' (2009) 12/13 Ghana Studies 15.

3 African Union Convention for the Protection and Assistance of Internally-Displaced Persons in Africa, adopted at the Special Summit of the African Union Heads of State and Government in Kampala, Uganda, 19-23 October 2009 (Kampala Convention).

4 In Mozambique, where coal constitutes about $61 \%$ of the country's minerals. See NA Besharati 'Raising Mozambique development through coal' South African Institute of International Affairs, Policy Briefing 56 September 20121.

5 M Lopes 'Miners Vale, Rio Tinto accused of neglecting displaced Mozambicans' Reuters 23 May 2013. 
to the west of Moatize town, ${ }^{6}$ there have been significant challenges with regard to their resettlement. ${ }^{7}$ One of the challenges faced by resettled communities in Cateme and Mwaladzi is the insufficiency of arable land for food production. Farmlands provided were not suitable for the production of 'staple crops' ${ }^{8}$ In Cateme, for instance, families were promised two hectares of land for farming in order to maintain their livelihood. ${ }^{9}$ However, only one hectare of land, described as 'unproductive farmland' - which was neither sufficient nor in close proximity to the houses of the resettlers - were provided. ${ }^{10}$ Prior to resettlement, those resettled in Mwaladzi to make way for the Benga mine had access to water from the Revuboe river in Capanga. 1 However, in Mwaladzi, water insecurity has been an issue. In the first phase of the resettlement in Mwaladzi, families were moved before the provision of water amenities. While, unlike the first phase, better access to water was provided for those moved in the second phase, the provision was still inadequate. ${ }^{12}$ In the resettlement of those displaced by Vale, there were discriminatory patterns. Households were deliberately divided into two, with the employed resettled in 25 de Setembro and the unemployed families resettled in Cateme village. Those resettled in 25 de Setembro were close to the mines and to Moatize and, as such, were close to the urban settlement. However, those relocated in Cateme village were 40 kilometres away from Moatize and experienced difficulties accessing jobs, being far away from the urban settlement. While creating geo-economic marginalisation, the resettlement kindles an impression that the

6 J Pedro 'Forced resettlements: From impacts to opportunities - The case of Moatize mine (Mozambique)' in A Afonso (ed) Informality and urbanisation in African contexts: Analysing economic and social impacts (2015) 6972.

71365 households living in Malabwe, Mithete, Chipanga and Bagamoyo were resettled by Vale within the period 2009 to 2010. The displaced persons were resettled in Cateme village and 25 de Setembro. Between 2009 and 2014, about 478 households were resettled from Capanga in the Tete region to Mwaladzi by Riverdale and Rio Tinto. During the first phase of the resettlement between 2009 and 2011, Riverdale and Rio Tinto resettled 85 households. It further resettled 358 households, comprising around 2100 individuals, between 2013 and 2014 . Human Rights Watch 'What is a house without food?' Mozambique's coal mining boom and resettlements (2013) 8 44; Lopes (n 5 above); S Lillywhite et al Mining, resettlement and lost livelihoods: Listening to the voices of resettled communities in Mualadzi, Mozambique (2015) 1-2.

8 Human Rights Watch (n 7 above) 8.

9 A Macheve 'The impact of coal mining on the living conditions of rural communities in Mozambique: A case study of Cateme' (2014) 64 https://open. uct.ac.za/bitstream/item/14692/thesis_hum_2014_macheve_aj.pdf?sequence=1 (accessed 19 April 2016).

10 C Jentzsch 'Mozambique: Photographs from the promised land' The Guardian 21 January 2013.

11 S Lillywhite 'Mining, resettlement and lost livelihoods: A case study of Mozambique' Devpolicy 21 July 2015.

12 Lillywhite et al ( 7 above) 15. 
'uneducated and unemployed members of a community can be dumped anywhere'. 13

Displacement within the context of gold mining in Ghana equally illustrates this concern. Between 1990 and 1998, over 30000 people were displaced for gold mining activities in the Tarkwa region. ${ }^{14}$ Although resettlement plans were often implemented by mining companies, in several instances the resettlement houses did not conform to the household sizes. ${ }^{15}$ However, there are certain instances where compensation was not offered. For instance, in 1997, 45 people were evicted from the Nkwantakrom community in the western region of Ghana ${ }^{16}$ to make way for the Ghanaian Australian Goldfields Mining Project (GAGMP) without proper consultation and compensation. ${ }^{17}$ In a case instituted before the Tarkwa High Court, GAGMP argued that the Nkwantakrom community had not existed prior to their acquisition of the mining concession, hence inferring that the members of the community were not only encroachers but had settled on the land for the purpose of attracting compensation. ${ }^{18}$ However, the Court rejected the argument, pointing out an underlying prejudice in the manner in which the community members had been treated. The Court observed that 'the attitude shown by the defendant right from the day of invasion [reveals] that the defendant [GAGMP] thinks of the plaintiffs [Nkwantakrom community] as weak and voiceless'. ${ }^{19}$ As such, they were to be 'quiet if a wealthy and influential multinational company demolishes their place of abode and uses their land in the way it likes'. ${ }^{20}$ This prejudice observed by the Court often resonates in the way in which displacement occurs in mining regions across Africa.

Another example is Kimberlite mining in Sierra Leone. Following the end of the war in Sierra Leone in the early 2000s, Koidu Holdings Limited (KHL) acquired mining rights in the Kono district for Kimberlite mining. In line with the Environmental Protection Act of $2000,{ }^{21} \mathrm{KHL}$ commissioned an environmental impact assessment (EIA) which revealed that 4537 people would be negatively affected. The

13 C Kabemba \& C Nhancale 'Coal versus communities: Exposing poor practices by Vale and Rio Tinto in Mozambique' Southern Africa Resource Watch, Open Policy 2 January 20125.

14 T Akabzaa \& A Darimani 'Impact of mining sector investment in Ghana: A study of the Tarkwa mining region' Structural Adjustment Participatory Review International (SAPRI), Draft Report 20 January 200144 http://www.saprin.org/ ghana/research/gha_mining.pdf (accessed 19 April 2016).

15 Akabzaa \& Darimani (n 14 above) 45.

16 Nana Kofi Karikari \& 44 Others v Ghanaian Australian Goldfields (GAG) Ltd (2007) Suit LS.34/97 (Karikari case).

17 As above.

18 Karikari case (n 16 above) 3.

19 Karikari case 6.

20 As above.

21 Network Movement for Justice and Development 'Diamonds, blood and tears: The relationship between Koidu Holdings Ltd and the affected property owners of Kono' Focus on Mining Companies Series 1 (April 2010) 16. 
EIA recommended that resettlement be carried out and the welfare of the vulnerable group be sought. However, KHL lingered for more than a year with the implementation of this recommendation, arguing that it was yet to make budgetary arrangements since the agreement it had with the government was to the effect that the land was vacant. ${ }^{22}$ As such, any occupation was illegal. After erecting a 'few shambolic housing', ${ }^{23}$ the company carried out blasting activities in contravention of the EIA. In early 2005, the local communities threatened massive protest, and in response KHL negotiated with the local communities and agreed that 'houses were to be constructed by community residents, and KHL was to bear the cost of construction materials, labour, and supervision'. ${ }^{24}$

In the context of oil mining, the situation in Sudan and Nigeria is instructive. In Sudan, between 1999 and 2002 the Greater Nile Petroleum Operating Company, comprising of a state-owned corporation in partnership with multinational companies such as Canadian-based Talisman, with the aid of the military engaged in the violent displacement of civilians for oil extraction. ${ }^{25}$ El Jack notes that 'reports ... documented that gunships regularly flew sorties form Heglig ... attacking civilian settlements as part of an ongoing campaign to control territory that could be used for oil development. ${ }^{26}$ Villages in the eastern part of Heglig were destroyed by army officials in 1999, and attacks were launched against the Ruweng County in the Western Upper Nile, displacing many individuals and leaving over 6000 houses burnt. ${ }^{27}$ According to a 2002 report, the United Nations (UN) Special Rapporteur on the Situation of Human Rights in Sudan, there were accounts of 'scorched earth tactics used by air and ground forces to clear oil-rich areas, chase people out of their villages and ensure that they would not return'.28

In Nigeria, much of the displacement in the Niger Delta region has been predicated on spills from oil extraction in the region which

\footnotetext{
22 Network Movement for Justice and Development (n 21 above) 15.

23 As above.

24 O Bermúdez-Lugo 'The mineral industry of Sierra Leone' (2005) 34 United States Geological Survey Mineral Yearbook 1.

25 A El Jack 'Gendered implications: Development-induced displacement in Sudan' in P Vandergeest et al (eds) Development's displacements: Ecologies, economics, and cultures at risk (2007) 6169.

26 As above.

27 L Moro 'Oil development-induced displacement in the Sudan' Sir William Luce Fellowship, Durham Middle East Papers 10 September 2009 13-14.

28 General Assembly 'Situation of human rights in the Sudan: Interim report of the Special Rapporteur of the Commission on Human Rights on the situation of human rights in Sudan, Gerhart Baum' Note by the UN Secretary-General, A/57/ 326 (20 August 2002) para 39.
} 
government figures estimate at more than 7000 between 1970 and $2000 .{ }^{29}$ In the 1970s, one such instance of oil spillage was in Igolu village in Isokoland as a result of the activities of Shell, resulting in the displacement of over 2000 individuals in $1973 .{ }^{30}$ In the 1980s, oil spillage from Texaco-operated Funiwa well and Agip-operated Ogada Brass pipelines in the Niger Delta region severely affected several communities. $^{31}$ In 1998, oil spillage at Osima creek in Bayelsa resulted in eight days of fire outbreaks, the destruction of an estimated 400 houses and the displacement of 130000 individuals. $^{32}$ Oil spillage from the Abiteye station operated by Chevron in the Delta state displaced over 10 communities and rendered hundreds of people homeless in 2007.33

Displacement for corporate agricultural investment has also featured across the continent. The situation of Kaweri Coffee Plantation (KCP) in Uganda is instructive. In 2000, the Neumann Kaffee Gruppe - a Hamburg-based multinational coffee company wanted to establish a location to produce Robusta coffee. Around this time, Uganda was implementing an agricultural policy as part of its Poverty Eradication Action Plan (PEAP), primarily aimed at reducing poverty in Uganda to 10 per cent by 2017 . $^{34}$ This agricultural policy the Plan for Modernisation of Agriculture (PMA) - was aimed at eradicating poverty 'through a profitable, competitive, sustainable and dynamic agricultural and agro-industrial sector'. ${ }^{3}$ In order to realise this goal, there were plans to convert subsistence-based agriculture to commercial agro-production. In this context, the purported investment by the Neumann Kaffee Gruppe was a timely

29 J Vidal 'Shell oil spills in the Niger Delta: "Nowhere and no one has escaped"' The Guardian 3 August 2011.

30 SR Akinola 'Resolving the Niger Delta crisis through polycentric governance system' paper presented during the Fall 2003 Colloquia, organised by the Workshop in Political Theory and Policy Analysis, Indiana University, Bloomington, USA, December 2003 20; LT Ajibade \& AA Awomuti 'Petroleum exploitation or human exploitation? An overview of Niger Delta oil producing communities in Nigeria' (2009) 3 African Research Review 111114.

31 I Okonta \& O Douglas Where vultures feast: Shell, human rights and oil (2003) 113; O Owolabi \& I Okwechime 'Oil and security in Nigeria: The Niger Delta crisis' (2007) 32 Africa Development 113.

32 CO Opukri \& IS Ibaba 'Oil-induced environmental degradation and internal population displacement in Nigeria's Niger Delta' (2008) 10 Journal of Sustainable Development in Africa 173184.

33 E Arubi 'Oil spill displaces 10 ljaw communities' Vanguard 13 February 2007.

34 MC Muduuli 'Uganda's poverty eradication action plan: National sustainable development strategy principles tested' presentation at the International Forum on National Sustainable Development Strategies (NSDSs), convened by the United Nations Department for Economic and Social Affairs (DESA) in Accra, Ghana, 7-9 November 2001 1; Ugandan Ministry of Finance, Planning and Economic Development 'Poverty reduction strategy paper: Uganda's poverty eradication action plan: Summary and main objectives' Poverty Reduction Strategy Paper March 2000.

35 Ministry of Agriculture, Animal Industry and Fisheries and Ministry of Finance, Planning and Economic Development 'Plan for modernisation of agriculture: Eradicating poverty in Uganda: Government strategy and operational framework' Government Strategy and Operational Framework Kampala, Uganda, 2000 VI. 
opportunity as such investment, which had the potential of realising the export-oriented agricultural transformation, could have a positive long-term impact on poverty eradication.

In 2001, the Ugandan government entered into an investment agreement with Neumann Kaffee Gruppe for the establishment of a large-scale coffee plantation in Uganda. For Neumann Kaffee Gruppe's large-scale investment in the coffee sector of Uganda's agricultural economy, the Ugandan Investment Authority acquired 2510 hectares of land from a freehold title holder by the name of Kayiwa and leased the land for a period of 99 years to the Neumann Kaffee Gruppe for the establishment of the KCP. ${ }^{36}$ However, the land was not vacant. Under Ugandan law, there is recognition of dual tenure of land, in which case both a registered title holder and a squatter, either as lawful or bona fide occupant, can have an interest in a piece of land. ${ }^{37}$ In situations where land inhabited by these occupants is sought to be expropriated, negotiations on compensation should take place. However, displacement was carried out without proper negotiations. ${ }^{38}$

In a meeting held on 15 June 2001, the occupants were told to vacate the land by 31 August $2001 .{ }^{39}$ They were informed that the landlord had acquired alternative land for their resettlement and would compensate them. ${ }^{40}$ Although lawful occupants - about 2 per cent of those evicted - were compensated, the land given 'often was too small ... [and] in some instances particular plots were allocated twice'. ${ }^{41}$ Bona fide occupants were neither compensated nor resettled. Before the expiry of the notice, between 17 and 21 of August 2001, about 401 peasant families (2 041 individuals) were forcibly evicted from their residences in four villages in the Mubende district of central Uganda to make way for the plantation. ${ }^{42}$ On

36 Neumann Kaffee Gruppe 'Chronology of events, Kaweri Coffee Plantation: 2000-2013' (2013) 1-2, http://www.nkg.net/userfiles/Documents/2013-04-16\% 20Chronologie\%20-\%20ENG.pdf (accessed 19 April 2016).

37 Art 29 of the Land Act defines both lawful and bona fide occupants. One distinguishing factor between lawful occupants and bona fide occupants is that lawful occupants reside on the land with the permission of the land owner, while bona fide occupants are those who have acquired an interest in the land by remaining on the land unchallenged by the registered holder for a period of 12 years. Uganda: Land Act, Cap 227 (1999), sec 29; C Mbazira 'Land grabbing in Uganda by a multinational corporation (World Court of Human Rights)' in M Gibney \& W Vandenhole (eds) Litigating transnational human rights obligations: Alternative judgments (2014) 186196.

38 C Mbazira 'Foreign investment and land grabbing' panel discussion at the Regional Seminar on ETOs and Access to Natural Resources, Kampala, Uganda 19 August 2014.

39 Baleke \& 4 Others v Attorney-General \& 2 Others (2013) UGHC 52 (Baleke case).

40 As above.

41 Wake Up and Fight for Your Rights Madudu Group and FIAN Deutschland Complaint against Neumann Kaffee Gruppe on violation of the OECD Guidelines for Multinational Enterprises (2009) $11 \mathrm{http}: / / w w w . o e c d w a t c h . o r g / c a s e s / C a s e \_167 /$ 788/at_download/file (accessed 19 April 2016).

As above. 
24 August 2001, KCP was inaugurated. Following its inauguration, agents of the Neumann Kaffee Gruppe cleared the area, uprooting the cultivated crops of those displaced from the land. ${ }^{43}$

In more recent times, large-scale agricultural investment projects by Chinese companies across Africa has heightened the risk of this form of displacement. ${ }^{44}$ In Nigeria, about 150000 farmers - representing 36 communities - are at risk of losing 12000 hectares of farmland following a Memorandum of Understanding between the Jigawa state government and a Chinese company for sugarcane plantation. ${ }^{45}$ Not only have these communities not been given alternative lands, but the compensation offered to them has been inadequate. ${ }^{46}$ As at 2014, about 10 million hectares of land had reportedly been acquired by Chinese firms across Africa for agricultural purposes. ${ }^{47}$ With growing food insecurity on the continent, such large-scale land grabs and displacement of communities only deepens the poverty crisis.

While revealing the magnitude of the problem, these cases underscore the need to address business-related development-induced displacement. International human rights law is clear on the obligation of states to regulate private actors in preventing violations of human rights by third parties. ${ }^{48}$ A combined reading of articles $3(1)(h),(1)(i)$ and 10 of the Kampala Convention requires states to address businessrelated development-induced displacement. However, the Kampala Convention does not provide the yardstick for assessing the responsibility of businesses. Within the context of the existing international framework on business and human rights, the article advances a discourse on what the responsibility of business entails. In

43 Baleke case (n 39 above).

44 R Adeola 'Why the African Union must press ahead with a business and human rights policy' The Conversation 8 May 2017.

45 VA Yusuf \& AM Hamagan '36 Jigawa communities lose farms to Chinese plantation' Daily Trust 9 February 2017.

46 S Tukur 'Investigation: How Jigawa government's land grab for Chinese firm threatens livelihood of 150000 citizens' Premium Times 7 April 2017.

47 A Saldinger 'How much agricultural land is China actually grabbing in Africa?' Devex 8 May 2014.

48 In Velásquez-Rodríguez $v$ Honduras, the Inter-American Court of Human Rights emphasised that a wrong act in violation of human rights which is not directly attributable to a state can invoke the responsibility of that state where the state fails to exercise due diligence in preventing a violation or ensuring accountability for such violation. In the NGO Forum case, the African Commission on Human and Peoples' Rights equally emphasised that a state will incur responsibility for acts of private actors where it fails to exercise due diligence. In Opuz v Turkey, the European Court of Human Rights inferred that due diligence obligation requires a state to take specific measures commensurate with the need to protect human rights against violations. In the SERAC case, the African Commission emphasised that this requires the establishment and preservation of an 'atmosphere or framework by an effective interplay of laws and regulations'. Velásquez-Rodríguez $v$ Honduras IACHR (29 July 1988) Ser C No 4 para 172; Zimbabwe Human Rights NGO Forum v Zimbabwe (2006) AHRLR 128 (ACHPR 2006) para 143; Opuz $v$ Turkey ECHR (9 June 2009) Application 33401/02 paras 148-149; Social and Economic Rights Action Centre (SERAC) \& Another $v$ Nigeria (2001) AHRLR 60 (ACHPR 2001) para 46. 
setting the stage, it is useful to consider corporate responsibility under international law.

\section{Corporate responsibility under international law}

The notion of corporate (or business) responsibility has been a subject of much contention in and outside international legal scholarship. As far back as 1970, Friedmann asserted that the responsibility of business was profit, ${ }^{49}$ and businessmen who speak of corporate responsibility are 'unwitting puppets of the intellectual forces that have been undermining the basis of a free society these past decades'.50 By this, Friedmann was casting aspersion on the notion of corporate social responsibility that had evolved in the seminal work of Abrams, Bowen and Keith and in the earlier intellectual debates of businessmen and scholars at the Harvard Business School in 1929 and 1932. ${ }^{51}$ Like Friedmann, Levitt described corporate social responsibility as a '[p]hilistinic form of self-flattery'. 52 However, the intellectual credence of such position has been challenged vigorously. Developments in the international sphere since 1972 have equally rendered the narrative of responsibility solely as profit redundant.

In 1972, the involvement of the US-based International Telegraph and Telephone Corporation in the political process in Chile instigated political debate on corporate responsibility in international law. ${ }^{53}$ The UN Economic and Social Council passed a resolution requesting the UN Secretary-General to engage eminent persons 'to study the role of multinational corporations and their impact ... also their implications for international relations'.54 Recognising that 'fundamental new problems have arisen as a direct result of the growing internationalisation of production as carried out by multinational corporations', ${ }^{55}$ the Group of Eminent Persons recommended that the complexities of these relations needed to be addressed without delay. The UN subsequently established a Commission on Transnational

49 M Friedmann 'The social responsibility of business is to increase its profit' The New York Times (13 September 1970).

50 As above.

51 See WB Donham 'Business ethics - A general survey' (1929) 7 Harvard Business Review 385; M Dodd 'For whom are corporate managers trustees' (1932) 45 Harvard Law Review 1153-1154; F Abrams 'Management's responsibilities in a complex world' (1951) 29 Harvard Business Review 29; H Bowen, Social responsibilities of the businessman (1953); D Keith 'Can business afford to ignore social responsibilities?' (1960) 1 California Management Review 70.

52 T Levitt 'The dangers of social responsibility' (1958) Harvard Business Review 41.

53 J Anderson 'Memos bare ITT try for Chile coup' (Washington Merry-Go-Round) The Washington Post 21 March 1972.

54 The UN Economic and Social Council Resolution 1721 (LIII), 2 July 1972.

55 UN Economic and Social Council 'The impact of multinational corporations on the development process and on international relations', Report of the Group of Eminent Persons to Study the Role of Multinational Corporations on Development and on International Relations, UN Doc E/5500/Add.1 (Part 1) 24 May 1974808. 
Corporations (UNCTC) to explore the 'possibility of concluding a general agreement on multinational corporations, enforceable by appropriate machinery, to which participating countries would adhere by means of an international treaty'. ${ }^{56}$ Accordingly, the UNCTC started to negotiate a Draft Code of Conduct on Transnational Corporations. ${ }^{57}$ Although in the end the process failed, the Draft Code reflected an overwhelming zeitgeist for corporate responsibility at the international level. ${ }^{58}$

In 1976, the Organisation for Economic Co-operation and Development adopted a Declaration on International Investment and Multinational Enterprises. ${ }^{59}$ In 1977, a Tripartite Declaration of Principles concerning Multinational Enterprises and Social Policy was adopted by the International Labour Organisation (ILO). ${ }^{60}$ Following the 1999 World Economic Forum in Davos, a set of Global Compacts for businesses was agreed, traversing, among others, principles on human rights and environmental protection. ${ }^{6 T}$ In 2003, a set of Draft Norms on the Responsibilities of Transnational Corporations and Other Business Enterprises was developed by a sessional Working Group set up by the Sub-Commission on Human Rights of the UN Commission on Human Rights. ${ }^{62}$ The Sub-Commission adopted these Draft Norms. While the Commission on Human Rights took no further action on the Draft Norms, ${ }^{63}$ it requested the UN Secretary-General in 2005 to 'appoint a special representative on the issue of human rights and transnational corporations'.64 Among other duties, the special representative was to 'identify and clarify standards of corporate responsibility and accountability for transnational corporations and other business enterprises with regard to human rights' ${ }^{65}$ In the same year, the UN Secretary-General appointed John Ruggie who, over a

56 UN Economic and Social Council (n 55 above) 835.

57 I Bantekas 'Corporate social responsibility in international law' (2004) 22 Boston University International Law Journal 309318.

58 KP Sauvant 'The negotiations of the United Nations Code of Conduct on Transnational Corporations' (2015) 16 Journal of World Investment and Trade 11 20.

59 Organisation for Economic Co-operation and Development OECD Declaration and Decisions on International Investment and Multinational Enterprises (1976).

60 Tripartite Declaration of Principles Concerning Multinational Enterprises and Social Policy, adopted by the Governing Council of the International Labour Office at its 204th session in Geneva, Switzerland (1977).

61 UN Global Compact 2000.

62 Draft United Nations Norms on the Responsibilities of Transnational Corporations and Other Business Enterprises with Regard to Human Rights UN Doc E/CN.4/ Sub.2/2003/12/Rev.2 26 August 2003.

63 DM Chirwa 'State responsibility for human rights' in MA Baderin \& M Ssenyonjo (eds) International human rights law: Six decades after the UDHR and beyond (2010) 409.

64 UN Commission on Human Rights 'Human rights and transnational corporations and other business enterprises' E/CN.4/RES/2005/6920 April 2005.

65 UN Commission on Human Rights para 1(a); T Thabane 'Weak extraterritorial remedies: The Achilles heel of Ruggie's "Protect, Respect and Remedy" framework and guiding principles' (2014) 14 African Human Rights Law Journal 4346. 
period of six years and 47 international consultations on all continents, developed the United Nations 'Protect, Respect and Remedy' Framework for Business and Human Rights (Guiding Principles). ${ }^{66}$

While there are discussions at the international level on a binding human rights framework on business and human rights, the Guiding Principles represents the first international consensus among states and businesses on corporate responsibility in international law, specifically with respect to human rights. Although non-binding, it has been hailed as 'a lasting beacon for business entities', 67 and 'guidance that will contribute to enhancing standards and practices with regard to business and human rights'. ${ }^{68}$

In understanding the responsibility of businesses in the context of development-induced displacement, the Guiding Principles are important. However, before this discussion is advanced, it is important to consider the normative framework on development-induced displacement in Africa. This is considered in the next section.

\section{Regional norm on development-induced displacement}

Article $10(1)$ of the Kampala Convention provides that 'as much as possible' development-induced displacement must be prevented. It is important to understand this provision in view of the objective of article 4(4) of the Kampala Convention, which seeks to prohibit 'arbitrary' displacement. ${ }^{69}$ While not placing an absolute prohibition on development-induced displacement, which will presuppose that all development projects likely to have a negative impact must to be stopped, the Kampala Convention seeks to mitigate the tension between the development imperative and human rights by setting two key requirements. First, there should be prior impact assessments before the implementation of development projects in line with article $10(3) .{ }^{70}$ Second, there should be informed consultation as required under article 10(2). ${ }^{71}$

66 UN Human Rights Council 'Guiding Principles on Business and Human Rights: Implementing the United Nations "Protect, Respect and Remedy" Framework' A/HRC/17/31 21 March 2011 (Guiding Principles).

67 'Business and human rights: Interview with John Ruggie' Business Ethics 30 October 2011.

68 UN Human Rights Council 'Human rights and transnational corporations and other business enterprises' A/HRC/17/L.17/Rev.1 15 June 2011 para 4.

69 For a discourse on arbitrary displacement in the context of development-induced displacement, see Adeola (n 1 above).

70 Art 10(3) of the Kampala Convention provides that '[s]tates parties shall carry out a socio-economic and environmental impact assessment of a proposed development project prior to undertaking such a project'. Kampala Convention (n 3 above) art 10(3).

71 Art 10(2) of the Kampala Convention provides that '[s]tates parties shall ensure 
A relevant question, resonating from the provision of article 10(2) of the Kampala Convention, is what kind of engagement or consultation is proposed. Should it be an engagement that seeks merely to legitimise or rubber-stamp projects, or should it be the meaningful involvement of persons likely to be displaced? In view of the accepted wisdom of proffering African solutions to African problems, it is essential to consider the nature of consultation in African traditions and customs. ${ }^{72}$ In Southern Africa, among the Tswana people of Botswana, there is a kgotla system, recognised by the government as a traditional institution for settling matters. ${ }^{73}$ At the kgotla, members of a community gather to deliberate on issues affecting them, and decisions in the kgotla are reached through consensus. ${ }^{74}$ Similar practices exist under the baito system in Eritrea and the gumi gayo system among the borana of Kenya and Ethiopia. ${ }^{75}$ Under these systems, the local assembly gathers to deliberate on issues of concern to the community and decisions are taken by consensus. ${ }^{76}$ Among the Maasai of Kenya and the Akans of Ghana, the lineages are the political entities. ${ }^{77}$ These lineages are represented in the town council by an abusua panyin who ensures that members of the lineages are consulted on issues affecting them. The significance of this is expressed in the proverb that 'one head does not go into council'78 and that 'wisdom is like a baobab tree; no one individual can embrace $\mathrm{it}^{\prime} .{ }^{79}$ These traditional mechanisms illustrate that consensual decision-making processes are integral to African

that the stakeholders concerned will explore feasible alternatives, with full information and consultation of persons likely to be displaced by projects'. Kampala Convention (n 3 above) art 10(2).

72 This rhetoric is often used to reinforce the need for a continent-conceived solution to continental challenges. In understanding the concept of human dignity, the African custom of ubuntu is often utilised as a societal valve. In conceptualising the role which the Panel of the Wise should play within the African Peace and Security Architecture, reference has been made to similar structures within African traditional systems. There is a growing consensus that conceptualisation and clarification for certain norms and institutions can be advanced by referring to African customs and traditions.

73 A Griffiths 'Between paradigms: Differing perspectives on justice in Molepolole, Botswana' (1996) 36 Journal of Legal Pluralism 195 197-200.

74 KC Sharma 'Role of traditional structures in local governance for local development: The case of Botswana' Paper for the Community Empowerment and Social Inclusion Programme, World Bank Institute (2003).

$75 \mathrm{~K}$ Tronvoll Mai Weini, a highland village in Eritrea: A study of the people, their livelihood, and land tenure during times of turbulence (1998) 277.

76 Bereketeab observes that the baito system is characterised by three significant features: '(i) direct democracy; (ii) consensus-based decision making; and (iii) the three functions of governance incorporated in one'. $\mathrm{R}$ Bereketeab 'Conceptualising civil society in Africa: The case of Eritrea' (2009) 5 Journal of Civil Society 3541.

77 FM Deng Identity, diversity, and constitutionalism in Africa (2008) 88; AA An-Na'im African constitutionalism and the role of Islam (2010) 37-38; A Leftwich Redefining politics: People, resources and power (2013) 73; HB Mitchell Root of wisdom: A tapestry of philosophical traditions (2014) 382.

78 SJ Salm \& T Falola Culture and customs of Ghana (2002) 61.

79 D Stewart \& C Swanson Wisdom from Africa: A collection of proverbs (2005) 10. 
traditional systems. Lending credence to this assertion, Ake argues that 'traditional African political systems were infused with democratic values. They were invariably patrimonial and consciousness was communal; everything was everybody's business, engendering a strong emphasis on participation. ${ }^{80}$ As such, consultation was a twoway deliberative process geared towards resolving issues and reaching certain goals.

The African concept and tradition of consultation is one that reflects the well-established notion of 'free, prior and informed consent'. The Kampala Convention similarly recognises the right of displaced persons to participate in decision-making processes and to make choices. Within the context of article 10(2) of the Kampala Convention, persons likely to be displaced are to be afforded the space to make and exercise choices on feasible alternatives to the development projects prior to its implementation. A question that derives from this assertion is how this should be realised in the context of development-induced displacement. In answering this question, it is necessary to examine the notion of free, prior and informed consent (FPIC).

In development practice, the notion of consent is contentious. The idea of project-affected persons being able to decide on the implementation of a project is often resisted as a developmental anathema. Much of the tension between states and indigenous communities in various parts of the world evinces this reality. In Africa, the situation is no less different given the displacement of indigenous populations across various parts of the continent for development projects. In a wave of evictions orchestrated by the Botswana government in 1997, 2002 and 2005, the San were removed from their settlements in the Central Kalahari Game Reserve (CKGR) to make way for tourism. ${ }^{81}$ Similarly, in Kenya, the Sengwer peoples in the Cherangany Hills were displaced in 2014 for the Natural Resource Management Project developed to harness natural resources and stimulate economic development. While an Indigenous Peoples' Planning Framework was developed emphasising participatory forest management, ${ }^{82}$ its objective was not respected. ${ }^{83}$ However, the displacement of indigenous communities without their FPIC is contrary to the international human rights obligations of states. ${ }^{84}$

80 C Ake 'Rethinking African democracy' (1991) 2 Journal of Democracy 3234.

81 Sesana \& Others $v$ Attorney-General (2006) AHRLR 183 (BwHC 2006).

82 Republic of Kenya 'Indigenous peoples' planning framework for the Western Kenya community driven development and flood mitigation project and the natural resource management project' 2006, Office of the President and Ministry of Water and Irrigation and Ministry of Environment and Natural Resources.

83 C Kline 'Sengwer of Kenya forcibly evicted from ancestral forest' IC Magazine 1 February 2014.

84 UN Committee on the Elimination of Racial Discrimination 'General Recommendation 23: Rights of indigenous peoples' UN Doc A/52/18 annex V (1997); United Nations Declaration on the Rights of Indigenous Peoples, UN Doc A/RES/61/295 13 September 2007. See AO Jegede 'Rights away from home: 
Under article 4(5) of the Kampala Convention, states are required to ensure the protection of 'communities with special attachment to, and dependency on, land due to their particular culture and spiritual values from being displaced from such lands, except for compelling and overriding public interests'.85 A pertinent concern from this provision is whether the fact that a project is for a 'compelling and overriding public interest' will constitute an exception to protecting indigenous populations. In seeking to avoid circumstances where the Kampala Convention may fall short of protection, articles 20(1) and (2) provide that no provision of the Kampala Convention shall be interpreted as affecting the existing protection of internally-displaced persons in international human rights law.

In international human rights law, FPIC is central to any expropriation of indigenous peoples' land and territories. The African Commission on Human and Peoples' Rights (African Commission) has equally emphasised that where a project will have a 'major impact' on indigenous peoples' land rights, their FPIC must be obtained. ${ }^{86}$ From the African Commission's jurisprudence, a state will not be excused from this duty because a project is for a 'compelling and overriding public interest'. It is important for FPIC to be understood as a continuum based on negotiations between the state and an indigenous population. Lending credence to this assertion, a 2017 report adopted by the African Commission's Working Group on Indigenous Populations/Communities emphasised that FPIC must be understood as 'a continual dialogue and negotiation between indigenous populations/communities and external actors engaged with activities on their lands' ${ }^{87}$

While it does not suggest a right to veto, what it implies is for states to foster an indigenous peoples-led model of development. In many cases, the arbitrary displacement of indigenous populations has been due to a neglect of this principle. In the case of the San peoples displaced from the CKGR, for instance, the government of Botswana could easily have arrived at a consensus with the San peoples through an indigenous peoples-led model of conservation which was sustainable, given that the San peoples had coexisted with the flora and fauna in the CKGR and their traditional knowledge had contributed to the development of the biomass.

Climate-induced displacement of indigenous peoples and the extraterritorial application of the Kampala Convention' (2016) 16 African Human Rights Law Journal 5875.

85 Art 4(5) Kampala Convention (n 3 above).

86 Centre for Minority Rights Development \& Others $v$ Kenya (2009) AHRLR 75 (ACHPR 2009) para 134.

87 African Commission on Human and Peoples' Rights and International Work Group for Indigenous Affairs Extractive Industries, Land Rights and Indigenous Populations'/ Communities' Rights, Report of the African Commission's Working Group on Indigenous Populations/Communities (2017) 44. 
While international human rights law is fairly established on the fact that obtaining consent is integral to the expropriation of indigenous peoples' lands, ${ }^{88}$ a significant concern relates to the applicability of this principle in relation to non-indigenous communities. From an ethical perspective, the refusal to obtain consent may constitute a denial of autonomy and dignity. However, a relevant question is whether the refusal to obtain consent in the context of developmentinduced displacement amounts to a violation of human rights. In answering this question, it is relevant to consider the notion of 'development', which is the narrative on development-induced displacement.

There are two significant approaches to understanding the notion of development: the traditional and the modern approaches. ${ }^{89}$ The crux of the traditional approach to development is development as economic growth to the exclusion of any socio-economic or environmental impact. However, in response to the realisation that growth in gross domestic income does not always translate into an increase in human capabilities, a significant shift emerged in development practice.

The modern approach to development incorporates those factors considered as externalities in the traditional approach, such as social, political, cultural and environmental concerns. Adopting a humancentric view of development, the modern approach to development requires that development plans, programmes and projects must be done with a view to increasing human capabilities. ${ }^{90}$ The right to development lends credence to this approach in emphasising that development encompasses 'economic, social, cultural and political' concerns. $^{91}$

In realising the right to development, participation is key. ${ }^{92}$ Participation not only validates the development process, but it also affords a space for meaningful engagement for individuals affected to determine the trajectory of development as they conceive it. Hence,

88 R Goodland 'Free, prior and informed consent and the World Bank Group' (2004) 4 Sustainable Development Law and Policy 66 67; B McGee 'The community referendum: Participatory democracy and the right to free, prior and informed consent' (2009) 27 Berkeley Journal of International Law 570 572; T Zvobgo 'Free, prior and informed consent: Implications for transnational enterprises' (2012) 13 Sustainable Development Law and Policy 37; M Barelli 'Free, prior and informed consent in the aftermath of the UN Declaration on the Rights of Indigenous Peoples: Developments and challenges ahead' (2012) 16 International Journal of Human Rights 1; P Hanna \& F Vanclay 'Human rights, indigenous peoples and the concept of free, prior and informed consent' (2013) 31 Impact Assessment and Project Appraisal 146.

89 DD Bradlow 'Development decision-making and the content of international development law' (2004) 27 Boston College International and Comparative Law Review 195.

90 Bradlow (n 89 above) 207.

91 Art 1 Declaration on the Right to Development UN Doc A/RES/41/128 4 December 1986.

92 Art 2(3) Declaration on the Right to Development (n 91 above). 
there is a level of consent to the process that should resonate. In the context of development projects, individuals bound to be affected by the development plan should be afforded the space to exercise consent where the trajectory of their own development is to be affected. Article $7(3)(c)$ of the UN Guiding Principles on Internal Displacement (GPID) iterates the centrality of consent to the protection of persons bound to be internally displaced by emphasising that the 'free and informed consent of those to be displaced shall be sought'.93 The Kothari Principles and the Kampala Convention, similarly, emphasise the pertinence of free and informed choice in fostering durable solutions to internal displacement concerns. ${ }^{94}$ Hence, while the refusal to 'obtain' consent may not violate human rights, the refusal to 'seek' consent will be at variance with international human rights law provisions.

There are two crucial requirements of the obligation to seek consent. First, the demands of persons likely to be displaced must be requested and given due consideration. The rationale for this requirement derives from the fact that legitimate consent can only be derived from an understanding of the demands of persons likely to be displaced. Second, there must be a deliberation process in which persons likely to be displaced are consulted and their demands are discussed with them with a view of reaching a reasonable compromise. In the process of seeking consent, it is important to ensure that civil society groups that can proffer constructive guidance in the deliberation process are involved. ${ }^{95}$

93 UN Commission on Human Rights 'Guiding Principles on Internal Displacement' UN Doc E/CN.4/1998/53/Add.2 11 February 1998 (GPID); see also UN Human Rights Council 'Basic principles and guidelines on development-based evictions and displacement' Doc A/HRC/4/18 annex I (5 February 2007) (Kothari principles); R Adeola 'The right not to be arbitrarily displaced under the United Nations Guiding Principles on Internal Displacement' (2016) 16 African Human Rights Law Journal 8395.

94 Art 11(2) Kampala Convention (n 3 above); para 56(e) Kothari Principles (n 93 above).

95 The benefit of civil society involvement resonates within the context of the Lesotho Highland Water Development Project (Highland Project). The Highland Project was birthed from a treaty between South Africa and Lesotho. The objective of the Highland Project was to give water to South Africa and electricity to Lesotho. For the creation of the project, a multi-dam scheme was developed. The first phase involved two sub-phases: $1 \mathrm{~A}$ and $1 \mathrm{~B}$. In Phase 1A, the Katse and Muela dams were constructed along the Malibamats'o and Nqoe Rivers. Over 20000 individuals were affected. In Phase $1 \mathrm{~B}$, the Mohale dam was created along the Senqunyane river. This dam affected about 7400 persons. Together, all three dams affected over 27400 people and led to the loss of grazing fields, arable lands and agricultural products which were sources of income of the affected communities. Through the involvement of civil society organisations, such as Transformation Resource Centre, the Highland Church Action Group, International Rivers, and Environmental Monitoring Group, key issues relating to the socioeconomic and environmental impacts of the Highland Project on project-affected persons have been spotlighted. Treaty on the Lesotho Highlands Water Project between the government of the Kingdom of Lesotho and the government of the 
Central to the notion of consent are three pertinent elements encased in the words 'free', 'prior' and 'informed'. 96 The word 'free' contemplates the absence of intimidation and manipulation. Within the contemplation of 'free' consent are four key requirements. ${ }^{97}$ First, project-affected persons should be afforded an enabling environment to determine the timeline, location, language and format of deliberations. Second, the deliberation process must be transparent. Third, all categories of persons without recourse to gender or disability must be involved in the deliberation process. Fourth, deliberations should be devoid of coercion.

'Prior' consent requires that the process must be done before the implementation of the project. ${ }^{98}$ This is important to avoid rubberstamping the process and to grant project-affected persons adequate opportunity to engage in the consideration of feasible alternatives. There are three crucial preconditions to prior consent. First, projectaffected persons should be given time to comprehend and consider information on the intended project. Second, the information must be given prior to the initiation of the development project. Third, the duration of the deliberation process must be respected.

The third central theme of the consent process is information. The word 'informed' requires that adequate knowledge should guide the decision-making process. There are three key elements of 'informed'

Republic of South Africa (1986); ML Thamae 'A decade of advocacy for damaffected communities' in ML Thamae \& L Pottinger (eds) On the wrong side of development: Lessons learned from the Lesotho highlands water project (2006); $\checkmark$ Mashinini 'The Lesotho highlands water project and sustainable livelihood' Africa Institute of South Africa Policy Brief 22 (June 2010) 13 http://www.ai.org.za/wpcontent/uploads/downloads/2011/11/No-22.-The-Lesotho-Highlands-Water-Proje ct-and-Sustainable-Livelihoods.pdf (accessed 29 September 2016); Global Nonviolent Action Database 'Basotho people demand compensation for Lesotho Dam construction, 2001-2005' http://nvdatabase.swarthmore.edu/content/basothopeople-demand-compensation-lesotho-dam-construction-2001-2005 (accessed 29 September 2016); 'Lesotho Highlands Water Project: A dam fine mess' Pambazuka News 13 October 2005 http://www.pambazuka.org/land-environment /lesotho-highlands-water-project-dam-fine-mess (accessed 29 September 2016); PJ Nelson \& E Dorsey New rights advocacy: Changing strategies of development and human rights NGOs (2008) 128; PH Letsebe 'A study of the impact of Lesotho highland water project on residents of Khohlo-Ntso: Is it too late for equitable benefit sharing?' (2012) 39 http://wiredspace.wits.ac.za/bitstream/handle/10539/ 12271/Phoebe\%20Harward\%20Letsebe\%20Thesis.pdf?sequence=2 (accessed 29 September 2016); S Rosenberg \& RF Weisfelder Historical dictionary of Lesotho (2013) 413; S Christie "'White gold" leaves a dark stain in Lesotho' Mail and Guardian 5 September 2014; RK Hitchcock 'The Lesotho Highlands water project: Dams, development, and the World Bank' (2015) 3 Sociology and Anthropology 526527 532; R Meissner Interest groups, water politics and governance: A case of the Lesotho Highland Water Project (2015) 53-54.

96 To understand the doctrine of FPIC, it is relevant to consider the Guidelines on Free, Prior and Informed Consent developed by the United Nations Programme on Reducing Emissions from Deforestation and Forest Degradation Programme (UN-REDD Programme). These guidelines offer an insight into the normative content of FPIC. UN-REDD Programme Guidelines on Free, Prior and Informed Consent (2013).

97 See UN-REDD Programme (n 96 above) 18.

98 UN-REDD Programme 19. 
consent. ${ }^{99}$ First, the information must contain essential facts relating to the development project and how it will affect project-affected persons. Second, the information must be understandable by the various categories of project-affected persons, including persons with disabilities. Third, the information must be detailed and reliable. By implication, the information on which consent is based must be comprehensive and not altered or misrepresented.

Businesses are not left out of this obligation in article 10(1) of the Kampala Convention. To understand what is expected of businesses, the next section applies the Guiding Principles.

\section{Responsibility of businesses in development-induced displacement}

Under the Guiding Principles, the responsibility of businesses is to respect human rights. Businesses must refrain from taking actions that can violate human rights. In respecting human rights, businesses are required to exercise due diligence. ${ }^{100}$ Exercising due diligence means avoiding harm.

In relation to development-induced displacement, businesses must implement the two-fold requirement in avoiding harm. The Guiding Principles lend credence to this two-fold requirement.

Article 18 of the Guiding Principles requires businesses to ensure 'meaningful consultation with potentially affected groups'.101

99 As above.

100 This duty requires businesses to 'avoid infringing on the ... rights of others ... and address human rights impacts with which they are involved'. This duty requires businesses not to take any measures that will violate human rights and to ensure redress where these impacts occur during its activities. Some scholars have argued that there is a positive element to this obligation in addition to the obligation to refrain, as businesses are 'required not just to avoid the passive avoidance of harm' but also to take steps to ensure that such harm is addressed in accordance with human rights law. Muchlinksi argues that the positive element of this obligation is reflected in more detail in the obligation on businesses to exercise due diligence. Corporate due diligence contemplates the steps a corporation must take to ensure that the human rights impacts of its activities are prevented or addressed. Art 17 of the Guiding Principles sets out the perimeter of the due diligence obligation, requiring that it should encompass 'adverse human rights impacts' which a corporation 'may cause or contribute to through its own activities, or which may be directly linked to its operations, products or services by its business relationships'. Human Rights Council 'Protect, respect and remedy: A framework for business and human rights' Report of the Special Representative of the Secretary-General on the issue of Human Rights and Transnational Corporations and Other Business Enterprises, John Ruggie: Summary, A/HRC/8/5 7 April 2008; Guiding Principles (n 67 above) art 11; R Lindsay et al 'Human rights responsibilities in the oil and gas sector: Applying the UN guiding principles' (2013) 6 Journal of World Energy Law and Business 2 12; P Muchlinski 'Implementing the new UN corporate human rights framework: Implications for corporate law, governance and regulations' (2012) 22 Business Ethics Quarterly 145148.

101 Art 18(b) Guiding Principles (n 66 above). 
A 'meaningful' engagement in consultation will invariably foster a consensual outcome. In the commentary, the Guiding Principles require businesses to consult directly with affected groups 'to assess their human rights impacts accurately'. ${ }^{102}$ Such adequate assessment will be near impossible if consultation is merely an opinion-gathering process. Since the aim of such accurate assessment of the human rights impact of a proposed project is to address these impacts, seeking the FPIC of persons likely to be displaced is essential. ${ }^{103}$

The second responsibility on businesses is to conduct prior-impact assessment. ${ }^{104}$ An assessment of prior impacts of development projects will provide information for proper consultation with projectaffected persons on feasible alternatives to the project likely to occasion displacement. ${ }^{105}$ It equally gives an indication of the issues that may arise from the implementation of the development project requiring significant attention. While article 10(3) of the Kampala Convention mentions 'socio-economic' and 'environmental' impacts, the Guiding Principles specifically require human rights impact assessment. ${ }^{106}$ An application of human rights impact assessment ensures recourse to existing international human rights standards, including instruments relating to specific groups such as women, children, persons with disabilities and indigenous peoples. For persons with disabilities, such recourse will ensure that reasonable accommodation is made in the provision of resettlement. For indigenous peoples, a rights-based approach will foster respect for land rights and self-determination. Utilising human rights as the standard for impact assessment will ensure that disruptions that do not fall squarely within socio-economic and environmental impacts are assessed, such as cultural disruptions and disintegration of communal bonds intrinsic to the rights to culture, association and assembly.

In operationalising this two-fold requirement, three steps are pertinent in line with the Guiding Principles. First, a policy statement detailing respect for human rights must be adopted and internalised. In addition to reflecting human rights generally, businesses with operations that may occasion displacement should also reflect the protection of development-induced displaced persons in their policy statements. An example of a good human rights statement for reference is the Human Rights Policy of Coca-Cola which, while articulating respect for human rights, highlights nine thematic areas of relevance to Coca-Cola's bottling activities. ${ }^{107}$ Tullow Oil's Human Rights Policy Statement presents a best practice on incorporating FPIC

102 Art 18 Guiding Principles (Commentary).

103 This is equally consistent with art 7(3)(c) of the GPID. See GPID (n 93 above) art $7(3)(\mathrm{c})$.

104 Art 10(3) Kampala Convention (n 3 above).

105 See Adeola (n 1 above) 8-9.

106 Art 18 Guiding Principles (n 66 above).

107 The Coca-Cola Company Human Rights Policy (2014). 
in a policy statement. In its policy statement, Tullow Oil commits 'to obtain the informed agreement of project-affected communities early in the project cycle, and prior to major project developments or changes that would significantly affect them'. ${ }^{108}$ The Policy Statement further commits Tullow Oil to 'engage meaningfully with and obtain broad community support from impacted communities throughout the project life cycle' ${ }^{109}$ In incorporating prior impact assessments, businesses may consult the model utilised in BP's Business and Human Rights Policy. ${ }^{110}$ However, a more favourable approach is to articulate that international human rights standards will significantly inform the prior assessments of the impacts of a proposed project.

Second, there must be a systematic internalisation of the two-fold requirement 'into internal control and oversight systems' ${ }^{111}$ This is essential in building corporate culture of respect for human rights. A systematic internalisation of this requirement will require the training of staff including top-level management. Businesses will also need to ensure that they incorporate this requirement into contractual agreements with firms outsourced to address the needs of projectaffected persons. However, a central component of internalisation is the establishment of an operational level grievance mechanism that is independent, transparent and impartial and whose decisions are respected. The mechanism must fulfil the eight criteria set out in the commentary on article 31 of the Guiding Principles and significantly 'focus on reaching agreed solutions through dialogue'. ${ }^{112}$

A third step is tracking. Businesses should track the progress of their response to the two-fold requirement of preventing arbitrary development-induced displacement. ${ }^{113}$ Tracking is essential for businesses to be well-informed about their performance. ${ }^{114}$ The Guiding Principles require that tracking should be based on 'appropriate qualitative and quantitative indicators' ${ }^{115}$ and draw on responses from external and internal informers. ${ }^{116}$ Businesses should further employ means such as 'performance contracts', 'reviews', 'surveys' and 'audits' in evaluating their performance. ${ }^{117}$ Businesses

108 Tullow Oil Tullow Oil PLC Policy Statement: Human rights (2016).

109 As above.

110 BP's Business and Human Rights Policy reflects the commitment of the business 'to work to embed human rights into environmental and social impact assessments as appropriate'. BP Business and Human Rights Policy (2013).

111 UN Human Rights Council 'Business and human rights: Further steps toward the operationalisation of the "protect, respect and remedy" framework' Report of the Special Representative of the Secretary-General on the issue of human rights and transnational corporations and other business enterprises, John Ruggie, UN Doc A/HRC/14/27 9 April 2010 para 83.

112 Art 31 Guiding Principles (n 66 above) (Commentary).

113 Art 20 Guiding Principles.

114 As above.

115 Art 20(a) Guiding Principles.

116 Art 20(b) Guiding Principles.

117 As above. 
should develop means of receiving useful feedback from the projectaffected communities, external sources including civil society organisations, state and traditional mechanisms and also independent human rights experts which it employs to assess its human rights performance.

\section{Conclusion}

The emphasis in the Kampala Convention on business-related development-induced displacement is significant for two reasons. First, it recognises that development projects occasioning displacement on the continent are not implemented only by states but also by businesses. Second, it emphasises the need for businesses to assume a form of responsibility to displaced communities and to address the negative impact that may result from development projects. In understanding this responsibility, the article argues that the Guiding Principles are relevant. The Guiding Principles mandate businesses to respect human rights and, as such, to respect human rights standards in avoiding harm. In the context of developmentinduced displacement, this responsibility requires businesses to implement the two-fold requirement integral to preventing arbitrary development-induced displacement, namely, free, prior and informed consent and prior impact assessment. The article argues that in implementing this responsibility, businesses should adopt policy commitments detailing respect for human rights and the protection of development-induced displaced persons in line with the two-fold requirement. Businesses should internalise the commitment through training, contract documents and operational level grievance mechanisms. Businesses should also track progress and receive feedback on progress from external oversight and monitoring mechanisms. 